\title{
Implications of Methodist clergies' average lifespan and missional lessons learned from obituaries of deceased ministers
}

Author:

Lehlohonolo J. Mathibe ${ }^{1,2}$

Affiliations:

${ }^{1}$ Therapeutics and Medicine Management, Discipline of Pharmaceutical Sciences, University of KwaZulu-Natal, South Africa

${ }^{2}$ Ordained minister, Mobeni/ Montford, South Durban Circuit 703, Methodist Church of Southern Africa, South Africa

Correspondence to: Lehlohonolo Mathibe

Email:

mathibel@ukzn.ac.za

Postal address:

Private Bag X7, Congella,

Durban 4013, South Africa

Dates:

Received: 26 Feb. 2015

Accepted: 27 Mar. 2015

Published: 09 June 2015

How to cite this article:

Mathibe, L.J., 2015,

'Implications of Methodist

clergies' average lifespan and

missional lessons learned

from obituaries of deceased

ministers', HTS Teologiese

Studies/Theological Studies

71(3), Art. 2920, 8 pages.

http://dx.doi.org/10.4102/

hts.v71i3.2920

\section{Copyright:}

(C) 2015. The Authors.

Licensee: AOSIS

OpenJournals. This work is

licensed under the Creative

Commons Attribution

License.

\section{Read online:}

Scan this QR code with your smart phone or mobile device to read online.
We are born, we touch the lives of others, we die - and then we are remembered. For the purpose of this article, I have assessed from obituaries the average lifespan of the clergy (ministers) in the Methodist Church of South Africa (MCSA), who died between 2003 and 2014. These obituaries were published in the Yearbooks of the MCSA from 2004 to 2015. I also give attention to how the deceased ministers are remembered. The average lifespan of Methodist ministers is 72 years, and it is likely to increase to 74 years by 2023. This article discusses the implications of Methodist ministers' average lifespan and suggests that the clergy should be encouraged and enabled to retire at the age of 60 years. The following 12 themes (or missional lessons), mainly answering the question of how the clergy are remembered, emerged from the qualitative analysis of obituaries: they were gifted preachers of the gospel of Jesus Christ; they lived a balanced life; they were humble servants in Jesus' vineyard; they were sensitive storytellers with a deep sense of humour; they were community builders; they were leaders and meticulous in administration; they were prayer warriors; they loved and valued education; they were disciplined and principled; they enjoyed music; they worked hard for an everlasting peace on earth; and they were zealous stewards of God's creation.

\section{Introduction}

The author of Genesis 5 paid meticulous attention to the lifespan of several people of God who lived during the Old Testament times. Methuselah, for example, lived longer than anyone and died at the age of 969 years (v. 27), whilst Enoch failed to match his counterparts. The average lifespan of the nine servants mentioned in this chapter, including Adam and excluding Noah, is 847 years and three months. They lived long! Then, in Genesis 6:3, we hear how God reduced the human beings' lifespan to 120 years. And in Psalm 90:10, it is further reduced to 70 years, with a bonus of about 10 years. These passages make it abundantly clear that human beings are no longer living for a long period on earth due to diseases and violence, among other things. Therefore we need to constantly reflect on how our lives touch the lives of others and to make appropriate plans whenever possible.

Ministers, priests, pastors or the clergy (in particular), are called to give their congregation hope in the midst of pain and suffering. Consequently, many of them are remembered fondly. The clergies are human beings too. They serve, they laugh, they contribute towards pension funds and medical schemes, they pay tax, they grow old, they retire from active ministry, and they die. They (too) need to plan accordingly for all stations of life.

The purpose of this article is to use obituaries of clergies as narrative pedagogical tools to assess and reflect on the implications of the average lifespan of the ministers in the Methodist Church of Southern Africa (MCSA), and to argue that memories of the departed can be used as missional lessons.

\section{Data collection and analysis}

Information was collected from obituaries which were published in the Yearbooks of the MCSA. In order to work out the age at death for an individual minister, the year (and the month) of birth was subtracted from the year (and month) of death. To work out the average age at death per year assessed, the individual ages at death were added up and then the sum was divided by the total number of those who died during that year. Finally, to work out the average lifespan, the annual average ages at death were added up and the sum was divided by 12 (which represents the 12 year period, namely those who died between 2003 and 2014).

Analysis of qualitative data obtained from obituaries (mainly answering the question of how the ministers were remembered) was informed by Burnard's (1991:461-466) method of 
analysing transcripts in qualitative research. This method entails 14 steps, which include inter alia the composition of initial themes after reading the manuscripts several times, collapsing and colour coding initial themes and then pasting quotations with the same colour codes on a chart to facilitate rigorous analysis and interpretation of data. The themes were derived independently by the principal researcher, and are presented in order of their strength.

\section{Findings and discussions Methodist clergies' age at death}

The 189 obituaries published in the Yearbooks (2004-2015) of the MCSA were analysed. However, one eulogy was excluded from the quantitative analysis because of a missing date of birth. The centurion Methodist minister, Revd Manoto Jeremiah Letlabika, died at the age of 101 years and six months in 2010. Hence the annual average age at death in 2010 was 78 years (Figure 1).

Other ministers who died at a 'ripe old age' were Revs James Wesley Allen (98 years), Allie Maqubela Zim (98 years) and Elijah Joseph Mohlala (99 years) in 2003, 2012 and 2013 respectively. Three ministers who were sadly called to higher service at a tender age were Revs Eric Ramatebele (31 years and one month old), Siyabonga Lennox Sislana ( 31 years and 10 months old) as well as Matshediso Magdalene Makhudu (33 years and one month) who died in 2004, 2011 and 2012 respectively.

The average lifespan of the Methodist clergy who died between 2003 and 2014 was 71 years and seven months (with the standard deviation of 15 years). The annual average lifespan has always been above 70 years, except in 2009 and in 2014 when it decreased to 63 years and below, and it shows

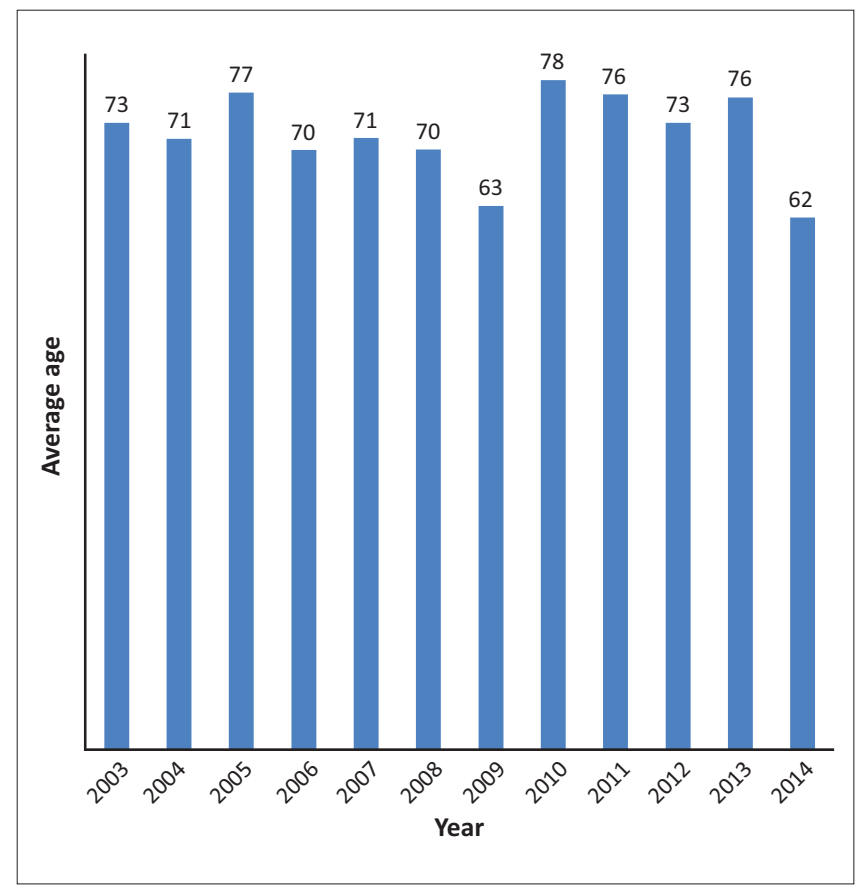

FIGURE 1: Methodist clergies' annual average ages at death from 2003 to 2014

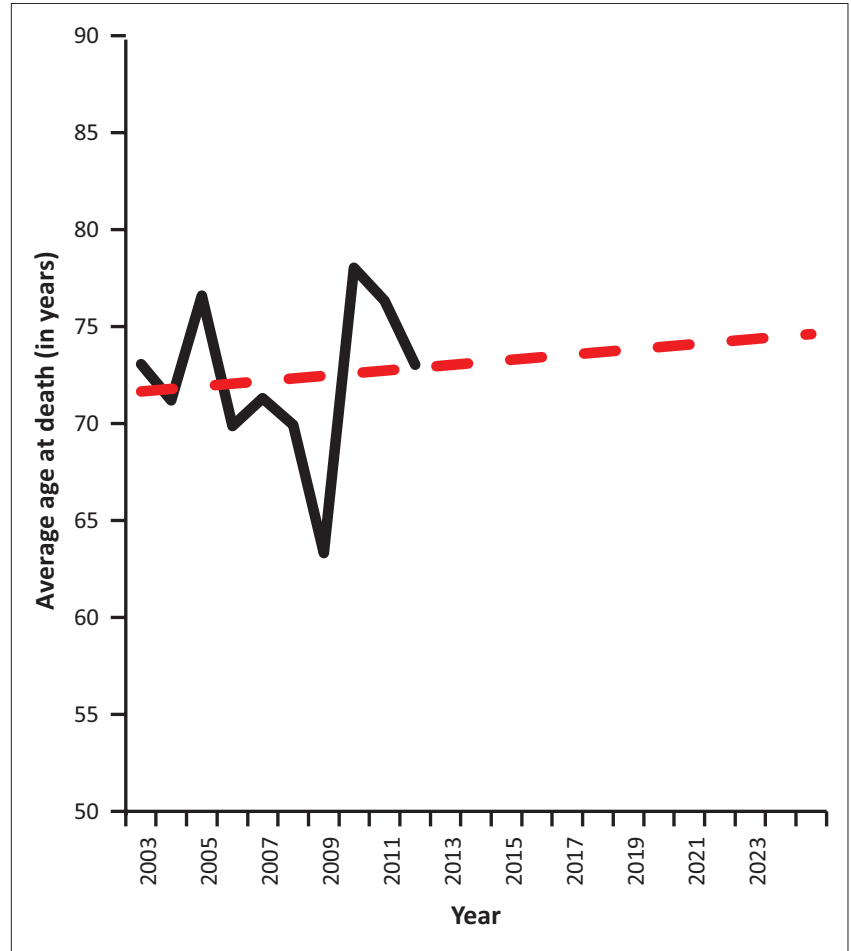

FIGURE 2: A linear projection (red dotted line) of Methodist clergies' average lifespan.

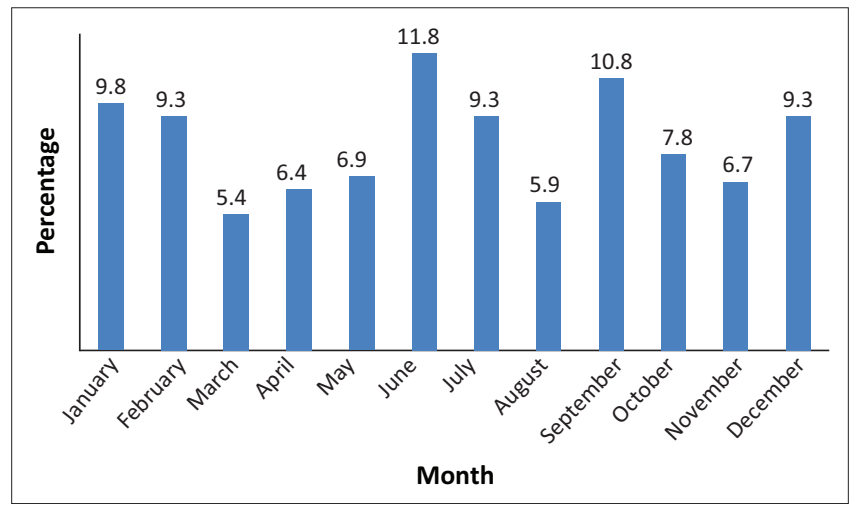

FIGURE 3: Death of Methodist ministers by months from 2003 to 2014.

an upward trend, with the probability of it increasing to 74 years in 2023 (Figure 2).

The findings do not show any significant differences in terms of the month of the year in which the death of ministers occurred (Figure 3). However, it was worth noting that June happened to be the month in which the largest proportion $(12 \%)$ of ministers died, while least (5\%) died in March.

\section{Implications of the lifespan of ministers}

The age at which the clergy die has many different implications. Firstly, these include, but are not limited to the age of entry (i.e. the candidature as it is known in the MCSA) into the 'Ministry of Word and sacrament'. In 2011, the Conference of the MCSA resolved that as from 2013, all candidates for the ordained full time itinerant ministry should be 50 years old or younger. This decision implies that 
on the average, ministers who offer for a full time ministry serve the church for at least 22 years before they are called to 'higher service' (i.e. before they die; are called to heaven).

Secondly, the retirement age is also affected by the average lifespan. For example, the Methodist Book of Order of the MCSA states that the normal maximum retirement age is 65 years (MCSA 2014:43). It means on average, ministers in the Methodist Church live for only seven years after retirement. Although it is assumed that many ministers 'die peacefully', a fair number of obituary writers expressed with sadness that ministers did not 'enjoy long years of retirement' (Yearbook 2005:383). Therefore one would suggest that ministers should be encouraged and allowed to retire at the age of 60 years.

However, an early retirement has vast consequences, which include the possibility of the church losing experienced leaders and individual ministers may forfeit additional income (i.e. additional stipend, manse and travelling allowances) which they receive while in active ministry. Again, the effects of accessing the pension pay-out early, the loss of connectedness and the impact of sedentary lifestyle on the life expectancy of those who retire early could be dire.

Many international studies have reported different and often contradicting outcomes on the effects of early retirement on life expectancy, and some with confusing and biased methodologies. For example, both the Shell Oil (Tsai et al. 2005:2) and the Greek EPIC (Bamia, Trichopoulos \& Trichopoulos 2007:563) studies have concluded that an early retirement shortens life expectancy. As a result of these and many other similar studies, ordinary people are encouraged, especially by the pension fund managers, to defer retirement. However, what is often not mentioned, is the fact that these studies have included the people who were forced to take early retirement because of ill health; the so-called 'health selection effects' as discussed by Quaade et al. (2002:221) and Hult et al. (2010:1483). Nevertheless, Brockmann, Muller and Helmert (2009) in their article, 'Time to retire - Time to die? A prospective cohort study of the effects of early retirement on long-term survival', got to the heart of the matter when they conclude:

Thus with respect to mortality, early retirement reflects both selective and protective processes. First of all, individuals with poor health and lower survival chances are filtered out of the labour market. However, healthy pensioners may be protected during retirement. For the former, early retirement is a necessity, for the latter it is an asset. Pension reformers should take health differentials into consideration when cutting back pension programs and increasing retirement age ... Severely sick people, as partners in an implicit intergenerational contract underlying all pay-as-you-go pension schemes and as victims of a significantly shorter life expectancy, have a legitimate right to obtain equivalent and early retirement payments to their more healthy peers. For them, not age but severity of the illness should be decisive for the timing of retirement. Healthy elderly people, however, stand to gain extended lifetime and pension payments from early retirement. (p. 164)
At the end of the day, every Methodist minister (in particular) needs to make a choice between working hard for the rest of their life, or to retire at the age of 60 years and enjoy, on average, the next and last twelve years of life - a rest before 'the rest'. Sadly, at the moment, the clergy seems content to continue to 'overpay for the future' (worldly) opportunities which they never get enough time to enjoy (Quoidbach et al. 2013:98).

\section{The Herald Sun (Cainer 2012), states:}

Mathematicians tell us that life is all about numbers. If we could only understand natural sequences, we could gain insight into the mind of the universe. Accountants also think that life comes down to numbers. If the balance sheet is healthy, all is well. If there is a deficit, all is bad. But life is not about numbers. It is about hearts and souls, celebration, communication (and) inspiration. (p. 35)

Indeed, in life it is not only the numbers (quantity) that matter, but what counts also is how one inspires or touches the lives of others.

\section{The ways the departed ministers are remembered}

The clergy by profession or by calling are meant to have a positive impact on the lives of others. When they are 'called to higher service', one can remember them with an abiding fondness. The following are 12 themes which emerged from the analysis of obituaries, published in the MCSA Yearbooks (2004-2015), and are presented here in the order of their strength.

\section{They were gifted preachers of the gospel of Jesus Christ}

The mission statement in the Yearbook (2015:2) of the MCSA proclaims that 'God calls the Methodist people to proclaim the gospel of Jesus Christ for healing and transformation'. Therefore it was not surprising that the departed ministers are remembered for the way they preached the gospel, because proclamation of the gospel is at the heart of the mission statement of the MCSA. Some comments focus on the character of the preacher:

- a fine preacher (Yearbook 2004:438)

- a distinguished magnetic preacher and speaker, preaching for a verdict and complete surrender at the foot of the Cross of our Lord and Saviour Jesus Christ (Yearbook 2008:294)

- a dynamic preacher and a great debater (Yearbook 2005:419)

- an excellent and passionate preacher who was always concise and insightful had a deep pastoral care (Yearbook 2004:444)

- a giant in the pulpit (Yearbook 2005:435)

- he was an eloquent and persuasive preacher (Yearbook 2004:454)

- was a powerful preacher, a faithful pastor, forceful leader (Yearbook 2005:391) 
- charismatic bible preacher, unshakable faith in Jesus Christ (Yearbook 2005:398).

Other comments focus on the impact and the quality of the sermons:

- very strict with church services and he planned his sermons meticulously (Yearbook 2005:390)

- his preaching was characterised by striking simplicity of language and purity of style (Yearbook 2005:425)

- a powerful preacher whose sermons were clear and converting and was centred around eternal life (Yearbook 2012:383)

- sermons were superbly crafted, full of challenging and exquisite prose, often spiced with humour which tellingly emphasised a vital point (Yearbook 2012:398)

- a sound preacher whose sermons were indicative of reading and research. His creative thinking was especially evident during the Local Preachers' Sundays in the way he crafted the order of Service and for his 'curious' themes (Yearbook 2013:367)

- a gifted preacher, meticulous and honest in his preparation and delivery (Yearbook 2015:282).

\section{They lived a balanced life}

In the Methodist Church, ministers are allowed to get married. Sometimes it is difficult to strike a balance between the needs of their family and the demands of the ministry. It is encouraging to note that the departed ministers are remembered as follows:

Being family persons:

- a loving husband and father (Yearbook 2004:424)

- could balance his time as a minister, father and husband (Yearbook 2004:449)

- he loved his family (Yearbook 2004:441)

- a great family man, loving and considerate (Yearbook 2004:430)

- a devoted family man, who insisted on his family time amidst the demands of the ministry (Yearbook 2005:423)

- was the best husband a wife could dream of and most fulfilling father and a friend any child could ever hope to have (Yearbook 2009:338)

- was a great family man, and was keen on family unity and good financial management (Yearbook 2012:371)

- there was nothing that pleased him more than having his family around him. In fact, he always felt that he had a licence to brag about his family to all who listened (Yearbook 2013:357).

Celebration of life:

- celebrated being human ... loved water, sweat, laughter and food (Yearbook 2004:435)

- was an excellent sportsman ... (Yearbook 2004:444)

- loved rugby and cricket and rarely missed any if there were big matches (Yearbook 2005:430)
- was active in sport, a very keen tennis player, cricket member. Had an enviable talent in horse-riding ... stickfighting was another of his passions (Yearbook 2008:283)

- excelled in sports such as rugby, surpassing himself in athletics (Yearbook 2009:344)

- was a fervent All Blacks (rugby) supporter ... enjoyed cooking (Yearbook 2010:294)

- was a dancer, tennis player and a conductor of choral music (Yearbook 2012:371)

- lived a balanced life, whilst Christian, and was not averse to socialising (Yearbook 2012:395)

- having gained distinction on athletics track as a student, his disciplined approach to living found expression, too, in his lifelong commitment to physical fitness (Yearbook 2011:361)

- he played cricket and soccer competitively (Yearbook 2011:362).

\section{They were humble servants in Jesus' vineyard}

Being a servant or serving with dignity is part of the requirements for the ministry. Hence the departed are remembered as:

- theologically honest, not afraid of admitting that he did not always see God, but he truly believed that God was always with him (Yearbook 2004:435)

- a faithful servant of Jesus (Yearbook 2004:438)

- his ministry touched many people especially students (Yearbook 2004:441)

- a simple and humble servant of the Lord (Yearbook 2007:298)

- passionate about his work (and loved to work in the rural areas) ... travelled the length by bicycle or scooter/horses or on foot (Yearbook 2004:448)

- one of the greatest servants of the Lord (Yearbook 2004:446)

- every task or duty which he performed was carried out with compassion and diligence (Yearbook 2005:433)

- whatever she did, she did it with sincerity and passion (Yearbook 2008:295)

- a hard worker (Yearbook 2009:351)

- was a loving, passionate and pleasant person who never craved for recognition and status and grew up in a very humble and obedient home (Yearbook 2010:286)

- he never complained, neither did he look for recognition or status (Yearbook 2014:402)

- he was a true shepherd (Yearbook 2015:381).

\section{They were sensitive storytellers with a deep sense of humour}

Storytelling formed a big part of Jesus Christ's teaching. Therefore it is encouraging that the Methodist clergy are sensitive storytellers and use humour to emphasise their critical points off and in the pulpit; for example, people mentioned that (the departed):

- had a great sense of humour and zest for living (Yearbook 2004:444; 2005:405; 2006:362) 
- his passion to fulfil God's call was tempered by humour, honoured by practically and energised by charity and goodwill (Yearbook 2005:382)

- displayed a deep sense of humour and he humbled himself (Yearbook 2005:417)

- had a dry sense of humour, always had time for a chat on the street corner or on the phone, ready to grow meaningful relationships (Yearbook 2005:410)

- had a wonderful smile ... smile which starts with his eyes - showing the inner light that motivates it (Yearbook 2006:362)

- had an endearing sense of humour, whether in the pulpit, living up the synod, or in conversation. Laughter for him was a gift that bore testimony to our hope as Christians (Yearbook 2010:288)

- a great storyteller and made many laugh when he related experiences of his ministry (Yearbook 2010:294)

- enjoyed socialising with people; with a joke and a laugh he communicated good cheer and an infectious faith in God (Yearbook 2012:377).

A comedy film in 1998, which brought back the memories of the life of Dr Patch Adams, (Patch Adams 1998) reminded us that humour heals. Indeed, when used appropriately inside and outside the pulpit, humour 'boosts spirits' and potentially improves health (Penson et al. 2005:652) and 'it mediates the impact of stressful life events' (Martin \& Lefcourt 1983:1315). Furthermore Tanay and her colleagues reported that humour enhances the feeling of togetherness and closeness (Tanay, Roberts \& Ream 2013:2133). It is therefore encouraging that ministers have 'an endearing sense of humour, whether in the pulpit, living up the synod, or in conversation. Laughter for [them is] a gift that bore testimony to our hope as Christians'. However, 'insensitive joking is offensive' (Tanay et al. 2013:2135).

\section{They were community builders}

The church needs to respond to the needs of the community where it is found. Therefore, it is imperative that the ministers immerse themselves in the activities of the communities and touch the lives of the people. It is encouraging that the departed played a critical role in the communities where they resided, as attested that she or he:

- was a pastor of the community and was always involved in community development (Yearbook 2005:426, 460)

- was active involved in community projects and politics (Yearbook 2005:413; 2007:305)

- offered his deep love to the community (Yearbook 2008:297)

- involved himself in various aspects of community development, among others agriculture, arts and culture; and was skilled in bricklaying (Yearbook 2009:344)

- contributed to community life in the capacity of chairman of the local school committee and ratepayers association (Yearbook 2011:355)

- immersed himself in community, he served on many committees and boards (Yearbook 2012:389)
- was a team player and active in community involvement and he built bridges between the church and the communities it serves (Yearbook 2013:379)

- took very seriously his Christian service to the community and was an ardent supporter of the World Vision, an international organisation that fights hunger in poor communities (Yearbook 2013:364).

\section{They were leaders and meticulous in administration}

As part of their duties, Methodist ministers are required to perform administrative duties such as chairing meetings and completing baptismal or funeral registers, among others. Therefore it is encouraging that the departed were regarded as being thorough in administration. Indeed, it is not only in the Methodist Church where ministers are expected to perform administrative tasks with diligence; because it was also reported that the first black Anglican priest to become the Archdeacon in the Church of the Province of Southern Africa, Revd Cameron Kenati Ngewu, 'left a legacy of his ability to manage and administer the church and its institutions' (Mbaya \& Ngewu 2008:60).

Some of the testimonies for departed Methodist ministers' with regards to administration of the church and its institutions are:

- they were fine administrators, trainers and leaders with dreams (Yearbook 2008:281; 2006:383; 2010:292; 2013:367)

- was known for time-keeping, impatience, abruptness, forth-right approach and short temper (Yearbook 2010:294)

- a fine administrator and a forceful leader (Yearbook 2005:392)

- had outstanding qualities of leadership (Yearbook 2005:398)

- was highly skilled in the conduct of meeting and meticulous in his administration (Yearbook 2006:363)

- the desk was kept meticulously tidy as matters requiring his attention were promptly dealt with and dispatched (Yearbook 2011:359)

- were very conscious of the value of time (Yearbooks 2005:390; 2012:372)

- a good administrator and he was a man of due dates (Yearbook 2009:342)

- was very strict with time management(Yearbook 2014:392).

\section{They were prayer warriors}

In Mark 9:29 Jesus says prayer has the power to bring healing. Therefore, the departed were indeed committed to prayers that heal. It is mentioned that:

- his prayers were revealing the reality and depth of his own personal walk with God (Yearbook 2004:454)

- they were commitment to personal prayer (Yearbook 2005:412)

- always leading people of God in worship and prayer (Yearbook 2009:355) 
- was always a man of prayer and one who expected God's Spirit to be active (Yearbook 2012:388).

\section{They loved and valued education}

In 2011 the Conference of the MCSA, asserted that 'due to the overwhelming challenges' facing public education in Southern Africa, the church needs to play an active role. As a result, the MCSA affirmed 'Christian Formation and Education' as one of the 'mission pillars'. Therefore it is encouraging to note that those who have been called to higher service:

- loved education ... you cannot be a good Christian if not educated because you cannot understand Christian English concepts fully ... have education, and represent black people with competence (Yearbook 2005:401)

- was a man of books (Yearbook 2005:405)

- was a man of studious nature who wanted to enhance his educational attainment to the highest possible pitch (Yearbook 2005:424)

- was a true academic who had a ferocious appetite for books (Yearbook 2005:410)

- they made outstanding contribution[s] to education (Yearbook 2008:280)

- his towering intellect was always with a burning zeal for sharing the gospel of Jesus Christ (Yearbook 2013:377)

- she loved reading, furthering her studies in accounting (Yearbook 2014:371).

\section{They were disciplined and principled}

Discipline and principles are bedrocks of good behaviour. The greatest impact is made when people live by their principles. Indeed, the departed were men and women of impeccable stature who commanded moral authority something needed today, especially by many young ministers whose character often compromises the witness of their contemporary colleagues and betrays the legacy of the departed. The deceased are remembered as those who:

- never compromised his principles for the sake of cheap popularity (Yearbook 2005:419)

- brought Methodist discipline and stability (Yearbook 2006:374)

- believed firmly in the Methodist Church - as an adherent of the Laws and Discipline and he implemented it the fullest (Yearbook 2006:378)

- disciplinarian, and yet engulfed by sympathy and real love for a sinner (Yearbook 2007:304, 309; 2012:385)

- was a man of integrity, high standards of morality and discipline (Yearbook 2010:279).

\section{They enjoyed music}

The mantra that Methodism was born in a song seems to be true, because for the departed:

- hymns had to be sung correctly and he enjoyed them immensely (Yearbook 2005:390)
- music was very dear to Rodger's heart, and the choir produced many a Cantata and regular weekly anthems (Yearbook 2007:308)

- loved music and could sing well (Yearbook 2009:339)

- his love for music continued through membership of Seniors' choir (Yearbook 2009:350)

- leading people of God in worship and prayer (Yearbook 2009:355)

- was passionate about church music and could sing well (Yearbook 2005:30; 2011:354)

- loved classical music, English literature as well as English and Afrikaans poetry, travel and adventure (Yearbook 2013:370).

\section{They worked hard for an everlasting peace on earth}

Conflicts are still rife in many communities throughout the world. Therefore it is encouraging that the departed worked hard for peaceful resolution of often violent situations. They are remembered as:

- peacemakers and teachers (Yearbook 2004:424)

- diplomats and peacemakers (Yearbook 2005:382)

- had a special gift of bringing peace (Yearbook 2005:435)

- was a peace-loving man - a man of stability (Yearbook 2009:358)

- he was in the fore-front of peace-making efforts, assisting those who fled their homes and supporting those who sought refuge in churches and promoted peace and reconciliation amongst the political groups in conflict, working mainly with leaders of the IFP (the Inkatha Freedom Party) and the ANC (the African National Congress) (Yearbook 2013:379).

Jesus Christ's saying that He came so that people may have a rich and satisfying life (Jn 10:10, NLT) was anchored on the world where there will be peace; which goes far beyond anything we can imagine (Phlp 4:7, NIV). I, therefore, believe that without peace there can be no celebration of life and all that it can offer. The faithful servants have indeed lived the words of Barack Obama (2013):

Peace is necessary ... Peace is just ... Peace is possible ... Peace begins - not just in the plans of the leaders, but in the hearts of the people. Not just in carefully designed processes, but in the daily connections.

\section{They were zealous stewards of God's creation}

These servants of God have truly played a role to ensure they leave the world as fertile as they themselves have inherited from their ancestors. They are remembered as servants who:

- had a passion for gardening and introduced congregants to a variety of plants and raising funds at the church bazaars with plant sales (Yearbook 2010:294)

- had a greatest love for ploughing (Yearbook 2004:448)

- was a gentleman who loved nature (Yearbook 2005:393)

- loved the garden, birds, travel, family and wildlife (Yearbook 2007:308) 
- enjoyed manual work in his workshop and garden; using his creative talents with tool and garden implements - he found a bonding with his Creator (Yearbook 2012:377)

- was an enthusiastic gardener; his gift for flower arrangement was often put to the service of his congregations as a delightful enrichment of his ministry (Yearbook 2013:355)

Two important things, among many perhaps, that were not explicit in how the departed Methodist ministers were remembered are the way they administered sacraments and their involvement in ecumenical movements. There was only one obituary writers who fondly mentions that the sacraments of baptism and Holy Communion were rightly administered' (Yearbook 2009:355) and another one says that the minister 'encouraged ecumenical services' (Yearbook 2013:364). Methodist ministers, although called into the ministry of Word and sacrament, are known to preach well and are required to preach well. Hence, they are remembered as 'giants in the pulpit' (Yearbook 2005:435). However, anecdotal evidence suggests that Methodist ministers are not as sensitive and careful towards the sacraments as they are with the Word. With regard to participation in interdenominational activities, I concur with Dandala that 'ecumenical engagement is not an optional extra, but central to the whole work of the MCSA' (Yearbook 2013:156). Perhaps the current Methodist ministers need to work harder on these two issues, because the tributes rendered for the departed have far-reaching implications for the living too.

\section{Reflection and conclusion}

God is immortal and human beings are to live for 70 years and some may reach 80 years. In this article I reported that the average lifespan of Methodist minsters is 72 years (or 71 years and seven months to be exact), which is about 11 years higher than the average South African life expectancy at birth. ${ }^{1}$ In South Africa, the rise in life expectancy in the recent years has been strongly associated with the roll out of HIV and AIDS treatment (Johnson et al. 2013:5). However, it will be speculative to associate higher life expectancy of Methodist clergy, as reported in this article, with the roll out of HIV and AIDS treatment, because data on HIV prevalence among Methodist ministers was not available. Instead, a comparison of the lifespan of Methodist clergy and that of ministers from other churches would be meaningful. However, as explained in the limitations section of this study, it was not possible to accurately assess the lifespan of ministers belonging to other church denominations.

The memories of departed ministers, however, live longer than the average lifespan of their mortal bodies. Many people whose lives had been touched by the deceased ministers continue to narrate their stories again and again. Therefore, obituaries provided an opportunity for a narrative theological reflection, because 'they embody the stories' of a community of the faithful. When doing a narrative theological reflection on the stories of the departed ministers, there is a possibility for one to be 'more incarnational' (Lucie-Smith 2007:7), because the story of God's mission is also narrated and reflected upon at the same time. Indeed, in narrative theology, the story of the lives of those who participated in God's mission 'is the story of our lives' (Van Huyssteen 1989:767). In this study, the 12 themes derived from the obituaries are in fact missional theses or lessons. Christopher J.H. Wright (2006:25) defined 'missional as simply an adjective denoting something that is related to or characterised by mission, or has the qualities, attributes or dynamics of mission'. Working for an everlasting peace on earth, which was fulfilled or attributed to by the departed ministers, was indeed at the centre of Jesus Christ's mission (Jn 14:27-28).

The advantages of obituaries as story-telling pedagogical tools go beyond being viewed only as the wells of inspiration for comforting the bereaved, or for remembrance. However, firstly it can strengthen the character of ministers to execute their call with authority, diligence and passion. Secondly, it can be used for spiritual formation at the theological seminaries where the next generations of ministers are being prepared to take over the baton of proclamation and ministry left by the deceased clergies. Thirdly, it can be 'useful in transmitting organisational values' (Denning 2011:126), in instilling the 'true spirit of Methodist discipline' as the Book of Order states (MCSA 2014:28) to communicate and to illustrate how one can live the Vision of the MCSA. Lastly, it can also be used to transform the worldview of the clergy and the lay people 'towards biblical worldview' - with regard to matters such as life, creation, love, peace and joy, marriage, good or evil, status, money, salvation and restoration and death (Hiebert 2008:265-305).

In conclusion, for those ordained and lay who are still on this side of the tomb, this article provides twelve or more things that can be learned from the homages of those who had been called to 'higher service'. Therefore until it is one's turn to be called, individual ministers and ordinary people can learn much and can hear God's story from the obituaries of deceased ministers.

\section{Limitations of this article}

This article relied on obituaries and testimonies which were mostly written by the friends of the deceased. The eulogies by nature and especially when written by friends, have a positive tone. Therefore there might be some other aspects (especially the negative ones) of the deceased that this article failed to extract.

Also, a fair number of tributes contained only hard and cold facts, namely the names of the Circuits and leadership positions the departed laboured in or held. It offers very little (or nothing) on the character and personality, or how the ministry of the deceased touched the lives of the people of God.

For comparison purposes, similar data was also sought from the Anglican, Presbyterian and the Catholic Churches 
in South Africa. Unfortunately it was not possible to obtain ages at death for the clergy who belonged to other churches. The following are some of the responses obtained:

This information you are looking for is in our past papers which includes a tribute to those ministers who have died. We don't collate and consolidate the information in a register and just refer to the Past Papers as and when required. (Mr Tom Coulter, Central Office, Presbyterian Church)

And:

Unfortunately we do not have a publication or manuscript of the kind. However, we do keep information files on deceased clergy to which we provide very limited access. I do not believe that these will be of assistance to you because some of them do not have the years and months of birth and death. (Ms Nomalungelo Ngcobo, Archives Assistant, Anglican Church, KwaZulu-Natal Diocese)

Concerted efforts were also made to access information on the deceased clergy in the Catholic Church. However, it was not possible to include these in this analysis because the readily available records do not include the dates of birth.

\section{Acknowledgements}

I am truly indebted to the following for promptly responding to my enquiries: Revd William Pool (Glenwood Presbyterian Church, Durban), Mr Tom Coulter (Clerk of Assembly and Principal Officer of the Pension Fun, Central Presbyterian Church, Johannesburg), the Methodist Connexional Office, the Methodist Publishing House in Cape Town, Revd Vido Nyobole (Secretary of Conference, MCSA), Mrs Hazel Stanley (receptionist, MCSA Natal Coastal District Office, Durban), Mrs Helen Barhoochi, (receptionist and the secretary of the Bishop - the Catholic Church, Durban Archdiocese), Ms Nomalungelo Ngcobo (Anglican Church, Natal Archdiocese, Pietermaritzburg), Mrs Elizabeth Nicolosi (K-RITH, Nelson R. Mandela School of Medicine, UKZN, Durban) for proofreading the initial draft manuscript, and more importantly, thank you to all authors of the 189 obituaries of ministers whose names appear in the MCSA Yearbooks between 2004 and 2015. Dedicated to the living and loving memory of the late Nondumiso Mercy 'MaShelembe' Khanya (1982-2014); to God be the glory.

\section{Competing interests}

The author declares that he has no financial or personal relationships which may have inappropriately influenced him in writing this article.

\section{References}

Bamia, C., Trichopoulos, A. \& Trichopoulos, D., 2007, 'Age at retirement and mortality in a general population sample - The Greek EPIC study', American Journal of Epidemiology 167(5), 561-569. http://dx.doi.org/10.1093/aje/kwm337

Brockmann, H., Muller, R. \& Helmert, U., 2009, 'Time to retire - Time to die? A prospective cohort study of the effects of early retirement on long-term survival',
Social Science and Medicine 69(2), 160-164. http://dx.doi.org/10.1016/j. Social Science and $M$
socscimed.2009.04.009

Burnard, P., 1991, 'A method of analysing interview transcripts in qualitative research', Nurse Education Today 11(6), 461-466. http://dx.doi.org/10.1016/02606917(91)90009-Y

Cainer, J., 2012, 'Horoscopes with Jonathan Cainer', The Herald Sun 13 January, 2012, p. 35.

Denning, S., 2011, The leader's guide to storytelling - Mastering the art and discipline of business narrative, Jossey-Bass, San Francisco, CA.

Hiebert, P.G., 2008, Transforming worldviews - An anthropological understanding of how people change, Baker Academic Publishing Group, Grand Rapids, MI.

Hult, C., Stattin, M., Janlert, U. \& Jarvholm, B., 2010, 'Timing of retirement and mortality - A cohort study of Swedish construction workers', Social Science and Medicine 70(10), 1480-1486. http://dx.doi.org/10.1016/j.socscimed.2009.10.043

Johnson, L.F., Mossong, J., Dorrington, R.E., Schomaker, M., Hoffmann, C.J., Keiser et al., 2013, 'Life expectancies of South African adults starting antiretroviral treatment: Collaborative analysis of cohort studies', PLOS Medicine 10(4) e100148, viewed 10 January 2015, from http://www.ncbi.nlm.nih.gov/pmc/ e100148, viewed 10 January 2015, from
articles/PMC3621664/pdf/pmed.1001418.pdf

Lucie-Smith, A., 2007, Narrative theology and moral theology - The infinite horizon, Ashgate, London.

Martin, R. \& Lefcourt, H.M., 1983, 'Sense of humor as moderator of the relation between stressors and moods', Journal of Personal and Social Psychology 45(3), 1313-1324. http://dx.doi.org/10.1037/0022-3514.45.6.1313

Mbaya, H. \& Ngewu, C.K., 2008, 'First black Archdeacon in the Church of the Province of Southern Africa: 1896-1987', Journal of Theology for Southern Africa 130(1), 54-73.

MCSA, see Methodist Church of Southern Africa, 2014, Methodist Book of Order.

Methodist Church of Southern Africa, 2014, Methodist Book of Order - The laws and discipline of the Methodist Church of Southern Africa, 12th edn., Methodist Publishing House, Cape Town.

Methodist Church of Southern Africa, 2004-2015, Yearbooks, Methodist Publishing House, Cape Town.

Obama, B., 2013, 'Remarks of President Obama in Address to the People of Israel', in The Whitehouse, viewed 24 December 2014, from https://www.whitehouse. gov/the-press-office/2013/03/21/remarks-president-barack-obama-people-israel

Patch Adams, 1998, motion picture, Universal Pictures, Mylander.

Penson, R., Partridge, R., Pudd, P. \& Seiden, M., 2005, 'Laughter: The best medicine?', The Oncologist 10(8), 651-660. http://dx.doi.org/10.1634/theoncologist.10-8-651

Quaade, T., Engholm, G., Johansen, A.M.T. \& Moller, H., 2002, 'Mortality in relation to early retirement in Denmark: A population-based study', Scandinavian Journal of Public Health 30(3), 216-222. http://dx.doi.org/10.1080/14034940210134022

Quoidbach, J., Gilbert, D.T., \& Wilson, T.D., 2013, 'The end of history illusion', Science 339(6115), 96-98. http://dx.doi.org/10.1126/science.1229294

Statistics South Africa, 2014, 'Life expectancy continues to rise as South Africa's population breaks 54 million', Statistics SA Publications, 1-18, Government Printers, Pretoria. Available from http://beta2.statssa.gov.za/?p=2973

Tanay, M.A., Roberts, J. \& Ream, E., 2013, 'Humour in adult cancer care: A concept analysis', Journal of Advanced Nursing 69(9), 2131-2140. http://dx.doi. org/10.1111/jan.12059

Tsai, S.P., Wendt, J.K., Donnelly, R.P., De Jong, G. \& Ahmed, F.S., 2005, 'Age at retirement and long term survival of an industrial population: Prospective cohort study', British Medical Journal 331(7523), 995. http://dx.doi.org/10.1136/ bmj.38586.448704.EO

Van Huyssteen, W., 1989, 'Narrative theology: An adequate paradigm for theological reflection?' HTS Teologiese Studies/Theological Studies 45(4), 767-77. http:// dx.doi.org/10.4102/hts.v45i4.2327

Wright, C.J.H., 2006, The mission of God - Unlocking the Bible's grand narrative, InterVarsity, Downers Grove, IL.

Yearbook, see Methodist Church of Southern Africa, 2004-2015, Yearbooks. 